\title{
UMPAN BALIK DAN GAYA KOGNITIF MATAKULIAH PEMBELAJARAN MATEMATIKA DI KEDIRI
}

\author{
Sofwan Hadi \\ STAIN Ponorogo \\ Email: sofwan@stainponorogo.ac.id
}

\section{Tersedia Online di \\ http://www.jurnal.unublitar.ac.id/ index.php/briliant}

\begin{tabular}{l}
\hline Sejarah Artikel \\
\hline Diterima pada 22 Januari 2017 \\
Disetuji pada 25 Januari 2017 \\
Dipublikasikan pada 1 Februari \\
2017 Hal. 113-123 \\
\hline
\end{tabular}

\section{Kata Kunci:}

Umoan balik, gaya kognitif, pembelajaran matematika kelas rendah

\begin{abstract}
Abstrak: Penelitian bertujuan untuk menemukan dan menganalisis secara empiris tentang bentuk umpan balik dan gaya kognitif terhadap kemampuan kognitif siswa. Subjek penelitian adalah mahasiswa yang menempuh mata kuliah Pembelajaran Matematika di Kelas Rendah PGSD UNP Kediri. Pemilihan kelas dilakukan dengan membuat kelas eksperimen dan kelas kontrol, dilanjutkan dengan pengelompokan mahasiswa masing-masing kelas ke dalam dua gaya kognitif yang berbeda. Rancangan penelitian yang digunakan dalam penelitian ini adalah desain faktorial $2 \times 2$. Hasil menunjukkan tidak terdapat interaksi antara bentuk umpan balik dengan gaya kognitif mahasiswa terhadap kemapuan kognitif pada mata kuliah Pembelajaran Matematika di Kelas Rendah.
\end{abstract}

Pembelajaran efektif adalah pembelajaran yang mampu menggerakkan siswa untuk bertindak aktif dan positif, menyenangkan, bersemangat, dan penuh gairah. Interaksi antar peserta didik perlu dibangun sedemikian rupa sehingga aktivitas pembelajaran bisa mencapai target pembelajaran. Interaksi antar mahasiswa dengan dosen sebaiknya dikembangkan pada alur yang menyenangkan, aktif dan mendidik. Pola interaksi ini perlu dikembangkan dengan baik salah satunya dengan pemberian umpan balik kepada mahasiswa. Umpan balik ialah komentar dosen terhadap hasil pekerjaan mahasiswa. Komentar ini dapat dilakukan secara tertulis pada pekerjaannya atau secara lisan, langsung kepada siswa yang bersangkutan. Selain dari dosen, umpan balik dapat juga diperoleh dari aktivitas siswa saat berinteraksi dengan temannya. Harsanto (Ardana, 2008) menjelaskan peningkatan kualitas pendidikan dapat dilakukan melalui pendekatan belajar yang sesuai dengan karakteristik materi dan kondisi peserta didik. Sehingga pembelajaran perlu disusun berdasarkan gaya kognitif dari siswa. Menurut Nasution, gaya kognitif adalah cara yang konsisten yang dilakukan oleh seorang siswa dalam menangkap stimulus atau informasi, cara mengingat, berpikir, dan memecahkan soal (Nasution, 2007). Pada penelitian ini gaya kognitif akan dibedakan menjadi field independent dan field dependent. Menurut Sudjana, orang yang bergaya field independent cenderung kurang dipengaruhi oleh lingkungan dan oleh pendidikan di masa lampau (Sudjana, 2005,

113 BRILLIANT: Jurnal Riset dan Konseptual Volume 2 Nomor 1, Februari 2017 
hal. 95). Orang yang mempunyai gaya kognitif field independent memiliki karakteristik individual yang dominan ketika mengerjakan tugas atau beraktivitas pembelajaran. Menurut Nasution, orang yang bergaya field dependent cenderung dipengaruhi oleh lingkungan dan oleh pendidikan di masa lampau (Nasution, 2007). Orang yang mempunyai gaya kognitif field dependent penuh motivasi apabila berinteraksi dengan orang lain selama pembelajaran.

Selain gaya kognitif, pemberian umpan balik perlu diperhatikan selama pembelajaran. Gaya Kognitif mempengaruhi proses perkembangan Zona Proximal Developments Siswa. Perkembangan Zona Proximal Development Siswa dipengaruhi oleh bantuan akibat umpan balik dari guru (Sofwan Hadi, 2008). Pemberian Umpan balik bisa memberikan motivasi terhadap hasil pembelajaran. Cole dan Chan, umpan balik tiada lain merupakan informasi yang diberikan kepada individu atas aksinya atau aktivitasnya yang berbentuk skor dari suatu hasil ujian, komentar dalam tugas, dan jawaban atas pertanyaan (Cole \& Chan, 1994: 242).

Umpan balik ini dikelompokkan menjadi 2 bentuk, yaitu umpan balik segera dan umpan balik tertunda. Umpan balik segera, peran siswa lebih aktif dibanding dengan peran dosen. Pada umpan balik ini, setiap jawaban tes yang benar diberi tanda benar, jawaban tes yang masih salah diberi tanda salah dan diberi petunjuk pembenaran, mahasiswa dituntut untuk memperbaiki jawaban yang masih salah hingga benar, dan dosen memberikan kesempatan kepada siswa untuk berkonsultasi. Pada umpan balik tertunda ini menurut, peran dosen lebih aktif dibanding dengan mahasiswa. Mahasiswa diberi kesempatan untuk mengkaji, menelaah, dan memperbaiki jawaban yang masih salah pada pertemuan tersebut. Dosen menjelaskan secara umum kesalahan-kesalahan itu secara klasikal di depan kelas dengan menggunakan metode ceramah.

Dari penjelasan di atas ditarik kesimpulan pada umpan balik segera adalah pemberian terdapat tanda benar atau salah dan petunjuk pembenaran sehingga mahasiswa dituntut untuk memperbaikinya dengan berkonsultasi langsung dengan dosen secara individu, sedangkan pemberian umpan balik tertunda pemberian informasi terhadap jawaban mahasiswa yang berbentuk deskripsi, komunikasi langsung, terprogram, terjadwal, menggunakan teknik tertentu, bersifat nyata, terbuka mengenai pengkajian dan penelaahan jawaban tes di mana pada umpan balik ini tidak terdapat tanda benar atau salah dan petunjuk pembenaran sehingga mahasiswa dituntut untuk memperbaikinya berdasarkan penjelasan dosen secara umum di muka kelas.

\section{METODE}

Penelitian dilaksanakan pada Program Studi PGSD, Fakultas Keguruan dan Ilmu Pendidikan Universitas Nusantara PGRI Kediri. Waktu penelitian adalah semester ganjil tahun akademik 2012/2013. Jenis penelitian yang dilakukan merupakan penelitian kuantitatif, desain ekspreimen penelitian yang digunakan adalah desain faktorial 2 x 2, bisa dilihat dari tabel 1 untuk lebih jelasnya: 
Tabel 1. Desain Faktorial 2 x 2 untuk Variabel Umpan Balik dan Gaya Kognitif

\begin{tabular}{|c|c|c|c|}
\hline Gaya Kognitif & 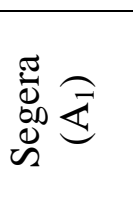 & 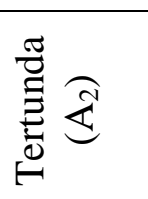 & $\frac{\text { 点 }}{\text { छ }}$ \\
\hline Field Independent $\left(\mathrm{B}_{1}\right)$ & $\mathrm{A}_{1} \mathrm{~B}_{1}$ & $\mathrm{~A}_{2} \mathrm{~B}_{1}$ & $\mathrm{~B}_{1}$ \\
\hline Field Dependent $\left(\mathrm{B}_{2}\right)$ & $\mathrm{A}_{1} \mathrm{~B}_{2}$ & $\mathrm{~A}_{2} \mathrm{~B}_{2}$ & $\mathrm{~B}_{2}$ \\
\hline Jumlah & $\mathrm{A}_{1}$ & $\mathrm{~A}_{2}$ & $\mathrm{~A} \times \mathrm{B}$ \\
\hline
\end{tabular}

Keterangan :

$\mathrm{A}_{1} \mathrm{~B}_{1}$ : kelompok siswa bergaya kognitif field independent yang diberi umpan balik segera.

$\mathrm{A}_{2} \mathrm{~B}_{1}$ : kelompok siswa bergaya kognitif field independent yang diberi umpan balik tertunda.

$\mathrm{A}_{1} \mathrm{~B}_{2}$ : kelompok siswa yang bergaya kognitif field dependent yang diberi umpan balik segera.

$\mathrm{A}_{2} \mathrm{~B}_{2}$ : kelompok siswa yang bergaya kognitif field dependent yang diberi umpan balik tertunda

Perlakuan terhadap subyek dalam penelitian ini berupa pemberian umpan balik. Umpan balik yang dimaksud adalah umpan balik segera dan umpan balik tertunda. Adapun perbedaan dari kedua perlakuan tersebut terletak pada adatidaknya petunjuk pembenaran yang diberikan dosen atas jawaban mahasiswa terhadap tes yang dilakukan. Petunjuk pembenaran ini selanjutnya akan menjadi umpan balik bagi siswa dalam melakukan perbaikan atas kesalahan dalam menjawab soal tes. Sebelum memberikan perlakuan, dosen melakukan diskusi dan pematangan konsep yang berkaitan dengan perlakuan. Adapun desain pembelajarannya dibuat sama termasuk suasana kelas, dan fasilitas tiap kelas. Yang membedakannya hanyalah perlakuan pemberian umpan baliknya saja. Adapun bentuk perlakuan bisa dilihat pada tabel 2 berikut.

Tabel 2. Prosedur Perlakuan dalam Penelitian

\begin{tabular}{|c|c|c|c|}
\hline No. & Aspek & Kelompok Eksperimen & Kelompok Kontrol \\
\hline 1. & $\begin{array}{c}\text { Umpan balik yang } \\
\text { digunakan }\end{array}$ & Umpan balik segera & Umpan balik tertunda \\
\hline 2. & Tanda koreksi hasil tes & Diberi tanda benar/salah & $\begin{array}{c}\text { Tidak diberi tanda } \\
\text { benar/salah }\end{array}$ \\
\hline 3. & Petunjuk jawaban salah & Diberikan & Tidak diberikan \\
\hline 4. & Teknik penilaian & $\begin{array}{c}\text { Setiap butir tes dan } \\
\text { keseluruhan butir tes }\end{array}$ & Keseluruhan butir tes \\
\hline 5. & $\begin{array}{c}\text { Teknik perbaikan jawaban } \\
\text { yang masih salah }\end{array}$ & $\begin{array}{c}\text { Dikaji dan ditelaah } \\
\text { secara individu oleh } \\
\text { mahasiswa dan dosen }\end{array}$ & $\begin{array}{c}\text { Dikaji dan ditelaah } \\
\text { secara umum di depan } \\
\text { kelas oleh dosen }\end{array}$ \\
\hline
\end{tabular}

115 BRILLIANT: Jurnal Riset dan Konseptual Volume 2 Nomor 1, Februari 2017 


\begin{tabular}{|c|c|c|c|}
\hline 6. & $\begin{array}{c}\text { Tuntutan perbaikan } \\
\text { jawaban yang salah }\end{array}$ & Dibuat ulang & Dibuat ulang \\
\hline 7. & $\begin{array}{c}\text { Hasil perbaikan jawaban } \\
\text { yang salah }\end{array}$ & $\begin{array}{c}\text { Diserahkan kembali } \\
\text { kepada dosen }\end{array}$ & $\begin{array}{c}\text { Diserahkan kembali } \\
\text { kepada dosen }\end{array}$ \\
\hline 8. & Pelayanan konsultasi & Individual & Klasikal \\
\hline 9. & $\begin{array}{c}\text { Waktu perbaikan jawaban } \\
\text { yang salah }\end{array}$ & $\begin{array}{c}\text { Ketika tatap muka } \\
\text { masih berlangsung }\end{array}$ & $\begin{array}{c}\text { Ketika tatap muka } \\
\text { masih berlangsung }\end{array}$ \\
\hline 10. & $\begin{array}{c}\text { Penjelasan ulang dari } \\
\text { dosen mengenai jawaban } \\
\text { yang salah }\end{array}$ & $\begin{array}{c}\text { Individual } \\
\text { Klasikal }\end{array}$ & $\begin{array}{c}\text { Mementingkan } \\
\text { kebersaman }\end{array}$ \\
\hline 11. & $\begin{array}{c}\text { Strategi perbaikan } \\
\text { Mementingkan }\end{array}$ \\
\hline 12. & Keterlibatan mahasiswa & Aktif & perbedaan individu \\
\hline
\end{tabular}

Data penelitian diolah dengan menggunakan statistik deskriptif sehingga diperoleh rangkuman tabel ANAVA untuk uji hipotesis berikut ini :

Tabel 3. ANAVA untuk Uji Hipotesis

\begin{tabular}{|c|c|c|c|c|c|c|}
\hline \multirow{2}{*}{ Sumber Varians } & \multirow{2}{*}{ db } & \multirow{2}{*}{ JK } & \multirow{2}{*}{ RJK } & \multirow{2}{*}{$\mathbf{F}_{\mathbf{h}}$} & \multicolumn{2}{|c|}{$\overline{\mathbf{F}_{\mathrm{t}}}$} \\
\hline & & & & & 0,05 & $\mathbf{0 , 0 1}$ \\
\hline Antar Kolom (Ak) & $\mathrm{db}(\mathrm{Ak})$ & $\mathrm{Jk}(\mathrm{Ak})$ & Rjk (Ak) & $\mathrm{F}_{\mathrm{h}}(\mathrm{Ak})$ & $F_{t}(A k)$ & $F_{t}(\mathrm{Ak})$ \\
\hline Antar baris $(\mathrm{Ab})$ & $\mathrm{db}(\mathrm{Ab})$ & $\mathrm{Jk}(\mathrm{Ab})$ & $\mathrm{Rjk}(\mathrm{Ab})$ & $F_{h}(A b)$ & $F_{t}(A b)$ & $F_{t}(A b)$ \\
\hline Interaksi (I) & $\mathrm{db}(\mathrm{I})$ & $\mathrm{Jk}(\mathrm{I})$ & Rjk (I) & $\mathrm{F}_{\mathrm{h}}(\mathrm{I})$ & $\mathrm{F}_{\mathrm{t}}(\mathrm{I})$ & $F_{t}(I)$ \\
\hline Antar Kelompok (A) & $\mathrm{db}(\mathrm{A})$ & $\mathrm{Jk}(\mathrm{A})$ & Rjk (A) & $F_{h}(A)$ & $F_{t}(A)$ & $F_{t}(A)$ \\
\hline Dalam Kelompok (D) & $\mathrm{db}(\mathrm{D})$ & $\mathrm{Jk}(\mathrm{D})$ & Rjk (D) & - & - & - \\
\hline Total di Reduksi (TR) & $\mathrm{db}(\mathrm{TR})$ & $\mathrm{Jk}(\mathrm{TR})$ & Rjk (TR) & - & - & - \\
\hline Retara/Koreksi (R) & $\mathrm{db}(\mathrm{R})$ & $\mathrm{Jk}(\mathrm{R})$ & Rjk (R) & - & - & - \\
\hline Total $(\mathrm{T})$ & $\mathrm{db}(\mathrm{T})$ & $\mathrm{Jk}(\mathrm{T})$ & 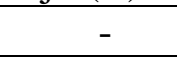 & - & - & - \\
\hline
\end{tabular}

(Supardi, 2008)

Keterangan pengisian tabel menggunakan aturan sebagai berikut (Supardi, 2008):

\section{Menentukan derajat kebabasan (db)}
(a) $\mathrm{db}(\mathrm{Ak})=\mathrm{k}-1$
(b) $\mathrm{db}(\mathrm{Ab})=\mathrm{b}-1$
(c) $\mathrm{db}(\mathrm{I})=(\mathrm{k}-1)(\mathrm{b}-1)$
(d) $\mathrm{db}(\mathrm{A})=\mathrm{k} \cdot \mathrm{b}-1$
(e) $\mathrm{db}(\mathrm{D})=\mathrm{n}_{00}-\mathrm{k} \cdot \mathrm{b}$
(f) $\mathrm{db}(\mathrm{TR})=\mathrm{n}_{00}-1$
(g) $\mathrm{db}(\mathrm{R})=1$
(h) $d b(T)=n_{00}$

\section{Menentukan jumlah kuadrat (JK)}



a) $J K(T)=\sum X_{00}^{2}$
b) $J K(R)=\frac{\left(\sum X_{00}\right)^{2}}{n_{00}}$
c) $J K(T R)=J K(T)-J K(R)$
d) $J K(A)=\left(\frac{\left(\sum X_{11}\right)^{2}}{n_{11}}+\frac{\left(\sum X_{12}\right)^{2}}{n_{12}}+\frac{\left(\sum X_{21}\right)^{2}}{n_{21}}+\frac{\left(\sum X_{22}\right)^{2}}{n_{22}}\right)-J K(R)$
e) $J K(A k)=\frac{\left(\sum X_{01}\right)^{2}}{n_{01}}+\frac{\left(\sum X_{02}\right)^{2}}{n_{02}}-J K(R)$
f) $J K(A b)=\frac{\left(\sum X_{10}\right)^{2}}{n_{10}}+\frac{\left(\sum X_{20}\right)^{2}}{n_{20}}-J K(R)$
g) $J K(I)=J K(A)-J K(A k)-J K(A b)$
h) $J K(D)=J K(T R)-J K(A)$

Menentukan Varians $\left(\delta^{2}\right)$ atau RJK :
a) $\operatorname{Rjk}(A k)=\delta^{2}(A k)=\frac{J K(A k)}{d b(A k)}$
b) $R j k(A b)=\delta^{2}(A b)=\frac{J K(A b)}{d b(A b)}$
c) $\operatorname{Rjk}(I)=\delta^{2}(I)=\frac{J K(I)}{d b(I)}$
d) $\operatorname{Rjk}(A)=\delta^{2}(A)=\frac{J K(A)}{d b(A)}$
e) $\operatorname{Rjk}(D)=\delta^{2}(D)=\frac{J K(D)}{d b(D)}$
f) $R j k(T R)=\delta^{2}(T R)=\frac{J K(T R)}{d b(T R)}$
g) $R j k(R)=\delta^{2}(R)=\frac{J K(R)}{d b(R)}$

\section{Menetukan Nilai $\mathbf{F}$ hitung $\left(\mathbf{F}_{\mathbf{h}}\right)$}
a) $F_{h}(A K)=\frac{\delta^{2}(A k)}{\delta^{2}(D)}$
b) $F_{h}(A b)=\frac{\delta^{2}(A b)}{\delta^{2}(D)}$
c) $F_{h}(I)=\frac{\delta^{2}(I)}{\delta^{2}(D)}$ 
d) $F_{h}(A)=\frac{\delta^{2}(A)}{\delta^{2}(D)}$

Menetukan Nilai $\mathbf{F}$ tabel $\left(F_{t}\right)=F\left(\alpha, d b_{1}, d_{b_{2}}\right)$

Catatan :

$$
\begin{aligned}
\mathrm{db}_{1} & =\mathrm{db} \text { pembilang }=\mathrm{k}-1 \\
\mathrm{db}_{2} & =\mathrm{db} \text { penyebut }=\mathrm{n}-1 \\
\mathrm{k} & =\text { Jumlah kolom/baris/perlakuan/kelompok } \\
n & =\text { Jumlah data/sampel }
\end{aligned}
$$

Selanjutnya data tersebut diolah untuk menarik kesimpulan hipotesis penelitian dengan melihat $\mathrm{F}$ hitung dan $\mathrm{F}$ tabel.

\section{HASIL}

Deskripsi data penelitian ini dikemukakan berupa skor terendah, skor tertinggi, rerata (mean), median, modus, ragam/varians dan simpangan baku/standar deviasi. Berdasarkan hasil analisis data yang dilakukan dengan menggunakan program Microsoft Office Excel 2007.

Nilai Mahasiswa yang Diberi Umpan Balik Segera terhadap Mata Kuliah Pembelajaran Matematika di Kelas Rendah

Uji coba instrumen penilaian mahasiswa terhadap mata kuliah Pembelajaran Matematika di Kelas Rendah memperoleh deskripsi data statistik secara empirik sebagai berikut: (1) skor terendah 55 dan tertinggi 90; rerata/mean 62.9; (3) median sebesar 60; (4) modus sebesar 60; dan simpangan baku sebesar 8.12.

Nilai Mahasiswa yang Diberi Umpan Balik Tertunda terhadap Mata Kuliah Pembelajaran Matematika di Kelas Rendah

Uji coba instrumen penilaian mahasiswa terhadap mata kuliah Pembelajaran Matematika di Kelas Rendah memperoleh deskripsi data statistik secara empirik adalah (1) skor terendah 60 dan tertinggi 87; (2) rerata/mean 68.9; (3) median sebesar 66; (4) modus sebesar 60; dan (5) simpangan baku sebesar 8.69 .

\section{Nilai Mahasiswa Bergaya Kognitif Field Independent terhadap Mata Kuliah Pembelajaran Matematika di Kelas Rendah \\ Uji coba instrumen penilaian mahasiswa terhadap mata kuliah} Pembelajaran Matematika di Kelas Rendah memperoleh deskripsi data statistik secara empirik sebagai berikut : (1) skor terendah 60 dan tertinggi 90; (2) rerata/mean 67.3; (3) median sebesar 64; (4) modus sebesar 60; (5) simpangan baku sebesar 9.52 .

Nilai Mahasiswa Bergaya Kognitif Field Dependent terhadap Mata Kuliah Pembelajaran Matematika di Kelas Rendah 
Uji coba instrumen penilaian mahasiswa terhadap mata kuliah Pembelajaran Matematika di Kelas Rendah deskripsi data statistik secara empirik sebagai berikut (1) skor terendah 55 dan tertinggi 80; (2) rerata/mean 64.5; (3) median sebesar 61.5; (4) modus sebesar 60; (5) simpangan baku sebesar 8.09. Untuk melihat distribusi frekuensi serta histogram dan poligon dari skor minat yang diperoleh.

\section{Nilai Mahasiswa Bergaya Kognitif Field Independent yang Diberi Umpan Balik Segera terhadap Mata Kuliah Pembelajaran Matematika di Kelas Rendah}

Uji coba instrumen minat mahasiswa terhadap mata kuliah Pembelajaran Matematika di Kelas Rendah memperoleh deskripsi data statistik secara empirik adalah (1) skor terendah 60 dan tertinggi 90; (2) rerata/mean 66.2; (3) median sebesar 62; (4) modus sebesar 60; (5) simpangan baku sebesar 9.86.

\section{Nilai Mahasiswa Bergaya Kognitif Field Dependent yang Diberi Umpan Balik Segera terhadap Mata Kuliah Pembelajaran Matematika di Kelas Rendah}

Uji coba instrumen minat mahasiswa terhadap mata kuliah Pembelajaran Matematika di Kelas Rendah memperoleh deskripsi data statistik secara empirik adalah (1) skor terendah 55 dan tertinggi 67; (2) rerata/mean 59.6; (3) median sebesar 60; (4) modus sebesar 60; (5) simpangan baku sebesar 4.2.

Nilai Mahasiswa Bergaya Kognitif Field Independent yang Diberi Umpan Balik Tertunda terhadap Mata Kuliah Pembelajaran Matematika di Kelas Rendah

Uji coba instrumen minat mahasiswa terhadap mata kuliah Pembelajaran Matematika di Kelas Rendah memperoleh deskripsi data statistik secara empirik sebagai berikut: (1) skor terendah 60 dan tertinggi 87; (2) rerata/mean 68.4; (3) median sebesar 65.5; (4) modus sebesar 60; (5) simpangan baku sebesar 9.56.

Nilai Mahasiswa Bergaya Kognitif Field Dependent yang Diberi Umpan Balik Tertunda terhadap Mata Kuliah Pembelajaran Matematika di Kelas Rendah

Uji coba instrumen minat mahasiswa terhadap mata kuliah Pembelajaran Matematika di Kelas Rendah memperoleh deskripsi data statistik secara empirik sebagai berikut : (1) skor terendah 60 dan tertinggi 80; (2) rerata/mean 69.4; (3) median sebesar 66.5; (4) modus sebesar 61; (5) Simpangan baku sebesar 8.21.

Analisis kognitif dilakukan dengan menggunakan ANAVA dua arah yang proses perhitungannya dibantu dengan program Microsoft Office Excel 2007. Hasil uji ANAVA tersebut kemudian dilanjutkan dengan uji $t$ untuk mengetahui signifikansi perbedaan diantara masing-masing kelompok secara signifikan (simple effect). Dengan kata lain, uji $t$ digunakan dengan tujuan untuk melihat kelompok sampel mana yang lebih tinggi minatnya terhadap mata kuliah Pembelajaran Matematika di Kelas Rendah.

119 BRILLIANT: Jurnal Riset dan Konseptual Volume 2 Nomor 1, Februari 2017 
Adapun ringkasan hasil analisis data dengan menggunakan ANAVA dapat dilihat pada tabel 4 berikut ini.

Tabel 4. Ringkasan Hasil ANAVA tentang Minat Mahasiswa terhadap Mata Kuliah Pembelajaran Matematika di Kelas Rendah

\begin{tabular}{|c|c|c|c|c|c|}
\hline SV & DK & JK & KT & F hit & $\begin{array}{c}\text { F tab } \\
(0.05) 1\end{array}$ \\
\hline $\begin{array}{l}\text { Rata-rata } \\
\text { Perlakuan }\end{array}$ & 1 & $173,712.40$ & $173,712.40$ & & \\
\hline A & 1 & 78.40 & 78.40 & 1.15 & 4.17 \\
\hline B & 1 & 360.00 & 360.00 & 5.26 & 4.17 \\
\hline $\mathrm{AB}$ & 1 & 144.40 & 144.40 & 2.11 & 4.17 \\
\hline $\begin{array}{l}\text { Kekeliruan } \\
\text { (E) }\end{array}$ & 36 & $2,462.80$ & 68.41 & & \\
\hline Total & 40 & $176,758.00$ & & & \\
\hline
\end{tabular}

\section{Keterangan :}

$\mathrm{A}=$ Gaya Kognitif

$\mathrm{B}=$ Umpan Balik

$\mathrm{AB}=$ Gaya Kognitif dan Umpan Balik

$\mathrm{DK}=$ Derajat Kebebasan

$\mathrm{JK}=$ Jumlah Kuadrat

KT =Kuadrat Tengah

\section{PEMBAHASAN}

Hipotesis Pertama : Kognitif mahasiswa yang diberi umpan balik segera lebih tinggi dari pada mahasiswa yang diberi umpan balik tertunda

Hasil data yang diperoleh dari pengukuran terhadap mata kuliah Pembelajaran Matematika di Kelas Rendah menunjukkan bahwa rerata skor mahasiswa yang diberi umpan balik segera adalah 62.9 sementara rerata skor mahasiswa yang diberi umpan balik tertunda adalah 68.9. Jika kedua rataan tersebut dibandingkan, terlihat bahwa rerata minat mahasiswa yang diberi umpan balik segera lebih tinggi dari pada rerata mahasiswa yang diberi umpan balik tertunda.

Perbedaan skor rerata juga ditunjang dengan hasil pengujian ANAVA untuk bentuk umpan balik. Berdasarkan Tabel 30 mengenai ringkasan hasil ANAVA, diperoleh harga $F$-hitung antar kolom sebesar 5.26 sementara harga $F$ tabel pada taraf signifikansi $\alpha=5 \%$ adalah 4.17. Jika dibandingkan, terlihat bahwa harga $F$-hitung antar kolom lebih dari harga $F$-tabel pada taraf signifikansi $5 \%$. Hasil tersebut menunjukkan hipotesis nol $\left(\mathrm{H}_{0}\right)$. Hal ini membuktikan bahwa terdapat perbedaan kognitif pada mata kuliah Pembelajaran Matematika di Kelas Rendah antara mahasiswa yang diberi umpan balik segera dengan mahasiswa yang diberi umpan balik tertunda. Mahasiswa yang diberi umpan balik segera 
( $\left.\mu A_{1}=68.9\right)$ memperoleh nilai yang lebih tinggi dari pada mahasiswa yang diberikan umpan balik tertunda $\left(\mu A_{2}=62.9\right)$ secara signifikan.

\section{Hipotesis Kedua : Kognitif mahasiswa yang bergaya kognitif field independent lebih tinggi dari pada mahasiswa yang bergaya kognitif field dependent}

Hasil data yang diperoleh pada mata kuliah Pembelajaran Matematika di Kelas Rendah menunjukkan bahwa rerata skor mahasiswa bergaya kognitif field independent adalah 67.3 sementara rerata skor mahasiswa bergaya kognitif field dependent adalah 64.5. Jika kedua rataan tersebut dibandingkan, terlihat bahwa rerata minat mahasiswa bergaya kognitif field independent lebih tinggi dari pada rerata mahasiswa bergaya kognitif field dependent.

Tetapi berdasarkan hasil pengujian ANAVA untuk kedua jenis gaya kognitif diperoleh harga $F$-hitung antar baris sebesar 1.15 sementara harga $F$ tabel pada taraf signifikansi $\alpha=5 \%$ adalah 4.17. Berdasarkan hasil tersebut, maka hipotesis nol $\left(\mathrm{H}_{0}\right)$ diterima. Hal ini membuktikan bahwa tidak ada perbedaan rerata (mean) antara mahasiswa bergaya kognitif field independent dengan mahasiswa bergaya kognitif field dependent adalah perbedaan yang signifikan. Mahasiswa bergaya kognitif field independent $\left(\mu B_{1}=67.3\right.$ memiliki kemampuan lebih tinggi dari pada mahasiswa bergaya kognitif field dependent $\left(\mu B_{2}=95,75\right)$ tetapi tidak signifikan perbedaannya.

Hipotesis Ketiga : Adanya interaksi antara bentuk umpan balik $(A)$ dan gaya kognitif $(B)$ terhadap kognitif mahasiswa pada mata kuliah Pembelajaran Matematika di Kelas Rendah

Hasil data yang diperoleh pada mata kuliah Pembelajaran Matematika di Kelas Rendah pada pemberian umpan balik segera menunjukkan bahwa rerata skor mahasiswa bergaya kognitif field independent $\left(\mu A_{1} B_{1}=69.4\right.$.) lebih tinggi dari pada skor rerata mahasiswa yang bergaya kognitif field dependent $\left(\mu A_{1} B_{2}=\right.$ 68.4). Sementara itu, pada pemberian umpan balik tertunda terlihat bahwa rerata skor mahasiswa bergaya kognitif field independent $\left(\mu A_{2} B_{1}=66.2\right)$ lebih tinggi dari pada rerata skor mahasiswa bergaya kognitif field dependent $\left(\mu A_{2} B_{2}=\right.$ 59.6). Data tersebut menunjukkan bahwa mahasiswa bergaya kognitif field independent lebih tinggi bila diberikan umpan balik segeradan yang tertunda.

Perbedaan skor di atas juga ditunjang oleh hasil ANAVA untuk melihat interaksi antara bentuk umpan balik dan gaya kognitif terhadap minat Pada Tabel 4.2 terlihat bahwa harga $F$-hitung interaksi adalah 2.11 sementara harga $F$-tabel pada taraf signifikansi $\alpha=5 \%$ adalah 4.17. Berdasarkan hasil tersebut, maka hipotesis nol $\left(\mathrm{H}_{0}\right)$ diterima.

Hasil penelitian pada kelompok mahasiswa dengan perlakuan umpan balik yang berbeda menunjukkan adanya perbedaan pada mata kuliah Pembelajaran Matematika di Kelas Rendah antara kelompok mahasiswa yang

121 BRILLIANT: Jurnal Riset dan Konseptual Volume 2 Nomor 1, Februari 2017 
mendapatkan umpan balik segera $\left(A_{1}\right)$ dengan kelompok mahasiswa yang mendapatkan umpan balik tertunda $\left(A_{2}\right)$. Perbedaan ini dapat dilihat dari perbedaan rerata skor minat yang diperoleh setiap kelompok tersebut. Rerata minat kelompok mahasiswa yang diberikan umpan balik segera $\left(\mu A_{1}=68.9\right)$ lebih tinggi dari pada rerata minat kelompok mahasiswa yang diberikan umpan balik tertunda $\left(\mu A_{2}=62.9\right)$. Perbedaan ini juga diperkuat dengan hasil ANAVA yang memperlihatkan harga $F$-hitung $(A)(5.26)$ lebih dari $F$-tabel pada taraf signifikansi $5 \%(4,17)$. Hasil ini memperkuat asumsi bahwa umpan balik yang berbeda akan memberikan hasil kognitif yang berbeda pula.

Pemberian umpan balik segera di mana dosen memberikan tanda benar atau salah serta petunjuk pembenaran atas hasil tes mahasiswa pada lembar jawabannya telah memberikan penguatan dan dorongan bagi mahasiswa untuk memperbaiki kesalahan pada tesnya. Perlakuan ini telah membantu mahasiswa keluar dari kesulitan pada mata kuliah tersebut. Lambat laun mulai tumbuh keyakinan tentang kemampuannya dalam mengikuti mata kuliah tersebut. Dampak secara individual, mahasiswa dapat belajar mandiri untuk meningkatkan kemampuannya. Sebaliknya, pada pemberian umpan balik tertunda, mahasiswa hanya memperoleh skor hasil tes saja tanpa tahu pada bagian mana letak benar dan salahnya. Perlakuan ini membuat mahasiswa tidak dapat menikmati mata kuliah tersebut. Ada mahasiswa yang merasa tidak beruntung dengan cara-cara yang dilakukan dosen dalam menjelaskan kesalahan-kesalahan yang masih dilakukan mahasiswa. Berdasarkan situasi ini, maka minat mereka terhadap mata kuliah Pembelajaran Matematika di Kelas Rendah tidak sebesar kelompok pertama.

Data di atas diperoleh melalui analisis statistik secara empirik terbukti bahwa kelompok mahasiswa yang diberikan umpan balik segera memiliki rerata minat yang lebih tinggi dibandingkan dengan kelompok mahasiswa yang diberikan umpan balik tertunda.

\section{KESIMPULAN}

Simpulan yang dapat diambil dari penelitian ini berdasarkan hasil pengujian hipotesis dan pembahasan hasil penelitian adalah sebagai berikut Mahasiswa yang diberi umpan balik segera memiliki kemampuan yang lebih tinggi terhadap mata kuliah Pembelajaran Matematika di Kelas Rendah dari pada mahasiswa yang diberi umpan balik tertunda. Mahasiswa yang diberi umpan balik segera memiliki rerata skor minat sebesar 62.9 dan rerata skor minat mahasiswa yang diberi umpan balik tertunda sebesar 62.9. Perbedaan minat di antara kedua kelompok ini adalah perbedaan yang signifikan. Ini ditunjukkan oleh hasil ANAVA di mana harga $F$-hitung $(A)(5.26)$ lebih dari $F$-tabel pada taraf signifikansi $5 \%(4,17)$. Berdasarkan hasil analisis ini, maka $H_{1}$ yang menyatakan bahwa rerata skor minat mahasiswa yang diberi umpan balik segera lebih dari rerata skor minat mahasiswa yang diberi umpan balik tertunda diterima, sehingga 
terdapat pengaruh bentuk umpan balik pada mata kuliah Pembelajaran Matematika di Kelas Rendah.

Mahasiswa yang bergaya kognitif field independent memiliki kemampuan sama terhadap mata kuliah Pembelajaran Matematika di Kelas Rendah dengan mahasiswa yang bergaya kognitif field dependent. Mahasiswa yang bergaya kognitif field independent memiliki rerata skor minat sebesar 67.30 dan rerata skor minat mahasiswa yang bergaya kognitif field dependent sebesar 64.50. Perbedaan di antara kedua kelompok ini adalah perbedaan yang tidak signifikan. Ini ditunjukkan oleh hasil ANAVA di mana harga $F$-hitung $(B)(1.15)$ kurang dari $F$-tabel pada taraf signifikansi 5\% (4.17). Tidak terdapat interaksi antara bentuk umpan balik dengan gaya kognitif mahasiswa terhadap kemapuan kognitif pada mata kuliah Pembelajaran Matematika di Kelas Rendah. Interaksi ini ditunjukkan oleh harga $F$-hitung interaksi (2.11) kurang dari $F$-tabel pada taraf signifikansi 5\% (4.17).

\section{SARAN}

Berdasarkan hasil penelitian di atas disarankan dosen mata kuliah Pembelajaran Matematika di Kelas Rendah dapat meningkatkan kemampuan kognitif mahasiswanya terhadap mata kuliah tersebut dengan cara sebagai berikut : Dosen dapat menggunakan pendekatan pembelajaran melalui pemberian umpan balik tes. Pemberian umpan balik tes merupakan sebuah cara untuk mengetahui tingkat keberhasilan mahasiswa dalam menyerap materi yang diberikan oleh dosen. Dosen dapat memilih pendekatan pembelajaran yang digunakan dalam menyampaikan materi dalam hal ini adalah bentuk umpan balik, Dosen dapat memberikan umpan balik tes kepada mahasiswa sesuai dengan gaya kognitifnya secara konsisten dan berkelanjutan agar tujuan pembelajaran mata kuliah tersebut tercapai.

\section{DAFTAR RUJUKAN}

Ardana, I. M. (2008). Peningkatan Kualitas Belajar Siswa Melalui Pengembangan Pembelajaran Matematika Berorientasi Gaya Kognitif dan Berwawasan Konstruktivis. Jurnal Penelitian dan Pengembangan Pendidikan, 1(1), $1-14$.

Cole, P. G., \& Chan, L. (1994). Teaching principles and practice. New York: Prentice Hall.

Nasution, D. (2007). Pengaruh Urutan Bukti, Gaya Kognitif, dan Personalitas Terhadap Proses Revisi Keyakinan. Universitas Gadjah Mada, Yogyakarta.

Hadi, Sofwan. (2008). Proses Konstruksi Pengetahuan Siswa Pada Pembelajaran Perbandingan Trigonometri. Universitas Negeri Malang, Malang.

Sudjana, N. (2005). Berbagai Pendekatan dalam Proses Belajar Mengajar. Bandung: Sinar Baru Algesindo.

Supardi. (2008). Diktat Kuliah: Aplikasi Statistik dalam Penelitian Pendidikan. Program Pascasarjana. 